\title{
Akut Brusellozis ve Brusellar Spondilodiskitte Serum Nötrofil Jelatinaz İlişkili Lipokalin Düzeyleri
}

\section{Serum Neutrophil Gelatinase-Associated Lipocalin Levels in Acute Brucellosis and Brucellar Spondylodiscitis}

\author{
Şua SÜMER (ID), Nazlım AKTUĞ DEMiR(ID), Lütfi Saltuk DEMiR²(ID), Duygu FINDIK(ID), \\ Servet KÖLGELIER ${ }^{4}$ (ID), Onur URAL ${ }^{1}$ (ID) \\ 1 Selçuk Üniversitesi Tıp Fakültesi, Enfeksiyon Hastalıkları ve Klinik Mikrobiyoloji Anabilim Dalı, Konya. \\ ${ }^{1}$ Selçuk University Faculty of Medicine, Department of Infectious Diseases and Clinical Microbiology, Konya, Turkey. \\ ${ }^{2}$ Necmettin Erbakan Üniversitesi Tıp Fakültesi, Halk Sağlığı Anabilim Dalı, Konya. \\ ${ }^{2}$ Necmettin Erbakan University Faculty of Medicine, Department of Public Health, Konya, Turkey. \\ ${ }^{3}$ Selçuk Üniversitesi Tıp Fakültesi, Tıbbi Mikrobiyoloji Anabilim Dalı, Konya. \\ 3 Selçuk University Faculty of Medicine, Department of Medical Microbiology, Konya, Turkey. \\ ${ }^{4}$ Dr. Abdurrahman Yurtaslan Ankara Onkoloji Eğitim Araştırma Hastanesi, Enfeksiyon Hastalıkları ve \\ Klinik Mikrobiyoloji Kliniği, Ankara. \\ ${ }^{4}$ Dr. Abdurrahman Yurtaslan Ankara Oncology Training and Research Hospital, Deparment of Infectious Diseases and \\ Clinical Microbiology, Ankara, Turkey.
}

*Bu çalışma, 30. Avrupa Klinik Mikrobiyoloji ve Enfeksiyon Hastalıkları (ECCMID) Kongresi (18-21 Nisan 2020, Paris, Fransa)'nde poster bildirisi olarak sunulmuştur. Bu çalışma, Selçuk Üniversitesi Bilimsel Araştırma Projeleri Koordinasyon Birimi tarafından desteklenmiştir (Proje No: 18401011).

Makale Atıfı: Sümer Ș, Aktuğ Demir N, Demir LS, Fındık D, Kölgelier S, Ural O. Akut brusellozis ve brusellar spondilodiskitte serum nötrofil jelatinaz ilişkili lipokalin düzeyleri. Mikrobiyol Bul 2022;56(1):1-10.

\section{ÖZ}

Brusellozis hücre içi bir bakteri olan Brucella spp.'nin neden olduğu zoonotik bir enfeksiyon hastalığıdır. Akut Brusellozisin komplikasyonları tüm organ ve sistemleri etkileyebilmektedir. En sık görülen komplikasyonu, kas iskelet sistemi tutulumudur. Nötrofil jelatinaz ile ilişkili lipokalin (NGAL), nötrofil oluşumunun bir belirtecidir ve bakteriyel demir alımını önlemek için siderofor bağlayıcı bir protein görevi görmektedir. Bu belirtecin bakteriyel enfeksiyonların tanı ve izleminde belirteç olarak kullanımı araştııımaktadır. Bu çalışma$\mathrm{da}$, akut Brusellozis ve Brusellar spondilodiskitli hastalarda NGAL serum düzeylerinin belirlenmesi, hastalığın seyri ve komplikasyonları ile serum NGAL düzeyleri arasında fark olup olmadığının değerlendirilmesi amaçlanmıştır. Bu prospektif vaka kontrol çalışması akut Brusellozis tanııı alan 240 hasta ve 120 sağlıklı kontrol grubu üzerinde gerçekleştirilmiştir. Akut Brusellozis tanısı; son sekiz hafta içinde ateş, halsizlik, eklem ağrısı, gece terlemesi gibi klinik semptomlar nedeniyle standart tüp aglütinasyon (STA) testi istenen kişilerde STA testinin 1/160 ve/veya üzerinde olması ya da Brucella STA testinde iki hafta arayla dört kat titre artışı saptanması ve/veya kan kültüründe Brucella spp. üremesiyle konulmuștur. Akut Brusellozis tanısı alan ve bel ağrısı şikayeti olan hastalardan kontrastlı lomber manyetik rezonans (MR) görüntüleme yapılmıştır. Radyolojik olarak spondilodiskit varlığı, kontrastlı lomber MR görüntüleri kullanılarak değerlendirilmiştir. NGAL düzeyleri "enzyme linked immunsorbant assay (ELISA)" testi ile saptanmıştır. NGAL ortanca değerleri akut Brusellozisli 
hastalarda $456.67 \mathrm{ng} / \mathrm{L}$ (101.41-5804.41 ng/L), kontrol grubunda NGAL ortanca değerleri $113.84 \mathrm{ng} / \mathrm{L}$ (58.29-542.34 ng/L) olarak saptanmıştır. NGAL ortanca değerleri, hastalarda istatistiksel olarak kontrol grubundan daha yüksek bulunmuştur ( $(=0.001)$. Akut Brusellozis tanısı alan 240 hastanın 57 (\%23.7)'sinde Brusellar spondilodiskit saptanmıştır. NGAL ortanca değerleri, Brusellar spondilodiskit saptanan hastalarda $1885.62 \mathrm{ng} / \mathrm{L}$ (143.21-5804.41 ng/L), Brusellar spondilodiskit saptanmayanlarda ise $356.87 \mathrm{ng} / \mathrm{L}$ (101.41$1874.07 \mathrm{ng} / \mathrm{L}$ ) olarak tespit edilmiştir. Bu fark istatistiksel olarak anlamlı bulunmuştur ( $p=0.001)$. Brusellar spondilodiskit saptanan hastalarda, eritrosit sedimentasyon hızı (ESR) ve C-reaktif protein (CRP) değerleri, Brusellar spondilodiskit saptanmayanlardan daha yüksek tespit edilmiştir. Akut Brusellozis tanısı alan 240 hastanın 186 (\%77.5)'sından kan kültürü alınmıştır. Kan kültürü pozitiflik oranı \%36.02 olarak belirlenmiştir. Kan kültüründe pozitiflik saptanan hastalarda NGAL düzeyi daha yüksek saptanmıştır $(p=-0.001)$. Brusellar spondilodiskit tanısı alan hastalarda kan kültürü pozitifliği oranı Brusellar spondilodiskit saptanmayanlara göre daha yüksek bulunmuştur $(p=0.001)$. Yapılan regresyon analizinde cinsiyeti kadın olmak, NGAL, ESR ve alanin aminotransferaz (ALT) yüksekliğinin Brusellar spondilodiskiti öngörmede kullanılabileceği tespit edilmiştir. Modelin açıklayıcılığı \%82.3 olarak bulunmuştur.

NGAL seviyelerinin belirlenmesi akut Brusellozis tanısında ve Brusellar spondilodiskit varlığını öngörmede yararlı bir belirteç olarak görülmekle birlikte, Brusellozisin endemik olduğu bölgelerde klinik pratikte kullanılabilmesi için daha kapsamlı çalışmalar gerekmektedir. lin.

Anahtar kelimeler: Akut Brusellozis; Brucella spp.; Brusellar spondilodiskit; nötrofil jelatinaz ilişkili lipoka-

\section{ABSTRACT}

Brucellosis is a zoonotic infectious disease caused by Brucella spp., an intracellular bacterium. The complications of acute Brucellosis may affect all organs and systems. The most common complication of the disease is musculoskeletal system involvement. The neutrophil gelatinase-associated lipocalin (NGAL) is a marker of neutrophil formation and acts as a siderophore-binding protein to prevent bacterial iron uptake and its use as a marker in the diagnosis and follow-up of bacterial infections is being investigated. The aim of this study was to measure the serum levels of NGAL in patients with acute Brucellosis and Brucellar spondylodiscitis, and to determine whether there is a correlation between NGAL levels and the progression and complications of the disease. This prospective case control study was conducted with 240 patients and 120 healthy controls. The diagnosis of acute Brucellosis was established when a person was asked to take an STA test due to clinical symptoms within the past eight weeks, and the test result that exceeded 1/160, or a 4-fold titer increase was found in the STA test after an interval of two weeks, and/or there was Brucella spp. growth in the blood culture. A contrasted lumbar magnetic resonance (MR) scan was performed on patients diagnosed with acute Brucellosis who had lower back pain. Presence of spondylodiscitis was assessed radiologically with contrasted lumbar MR images. NGAL levels were determined with ELISA assay. The median NGAL value was found to be $456.67 \mathrm{ng} / \mathrm{L}$ (101.41-5804.41 $\mathrm{ng} / \mathrm{L})$ in patients with acute Brucellosis and $113.84 \mathrm{ng} / \mathrm{L}(58.29-542.34 \mathrm{ng} / \mathrm{L})$ in the control group. The median NGAL value was statistically higher in the patients than the control group $(p=0.001)$. Brucellar spondylodiscitis was detected in 57 (23.7\%) of 240 patients diagnosed with acute Brucellosis. The median NGAL value was $1885.62 \mathrm{ng} / \mathrm{L}$ (143.21-5804.41 ng/L) in patients with Brucellar spondylodiscitis, and $356.87 \mathrm{ng} / \mathrm{L}(101.41-1874.07 \mathrm{ng} / \mathrm{L})$ in those who did not have Brucellar spondylodiscitis. This difference was statistically significant $(p=0.001)$. Erythrocyte sedimentation rate (ESR) and C-reactive protein (CRP) values were found to be higher in patients who had Brucellar spondylodiscitis. Blood cultures were drawn from $186(77.5 \%)$ of the 240 patients diagnosed with acute Brucellosis. The blood culture positivity rate was $36.02 \%$. Patients whose blood cultures were positive had higher NGAL levels $(p=0.001)$. The blood culture positivity rate was higher in patients who were diagnosed with Brucellar spondylodiscitis $(p=$ 0.001 ). A regression analysis showed that female gender and high levels of NGAL, ESR, and alanine aminotransferase (ALT) could be used as predictors of Brucellar spondylodiscitis. The explanatoriness of the model was $82.3 \%$. Although determination of NGAL levels is seen as a useful marker in the diagnosis of acute Brucellosis and predicting the presence of Brucellar spondylodiscitis, more comprehensive studies are required to be used in clinical practice in regions where Brucellosis is endemic.

Keywords: Acute Brucellosis; Brucella spp.; Brucellar spondylodiscitis; neutrophil gelatinase-associated lipocalin. 


\section{Giriş}

Brusellozis hücre içi bir bakteri olan Brucella spp.'nin neden olduğu zoonotik bir enfeksiyon hastalığıdır. Dünyada özellikle Akdeniz ülkelerinde, Hindistan, Orta Doğu, OrtaGüney Amerika ve Arap ülkelerinde sık görülmektedir ${ }^{1,2}$. Dünya Sağlık Örgütü (DSÖ) verilerine göre her yıl yaklaşık olarak 500.000 yeni olgu bildirilmektedir ${ }^{3}$.

Akut Bruselloziste uygun tanı ve tedavi protokollerine rağmen kronikleşme, relaps ve komplikasyonlar görülebilmektedir ${ }^{4-7}$. Akut Brusellozisin komplikasyonları tüm organ ve sistemleri etkileyebilmektedir. En sık görülen komplikasyonu kas iskelet sistemi tutulumudur. Kas iskelet sistemi komplikasyonları arasında spondilit, spondilodiskit, sakroileit ve büyük eklemleri tutan artrit sayılabilir. Brusellar spondilodiskit, akut Brusellozlu olguların \%10-21.4'inde görülmektedir ${ }^{1,8}$.

NGAL; doğal immün sistemin temel bileşeni olan antimikrobiyal bir moleküldür ${ }^{9}$. İnsan nötrofil lipokalin veya lipokalin 2 olarak da adlandırılan bu molekül başta nötrofiller olmak üzere birçok hücre ve dokuda (karaciğer, böbrek, kolon, akciğer, uterus, mide, prostat, tükrük bezi) bulunmaktadır ${ }^{9,10}$. Enfeksiyon, oksidatif stres, doku hasarı, hipoksi gibi farklı durumlarda serumda NGAL düzeylerinde artışlar izlenmektedir ${ }^{9,11,12}$. NGAL, nötrofillerin peroksidaz negatif granüllerinde, laktoferrin ile birlikte bulunur ve nötrofil aktivasyonunun ardından salınır. Granülosit, farklılaşma yolunun erken döneminde görülür ve bu nedenle nötrofil oluşumunun belirtecidir. NGAL, bakteriyel demir alımını önlemek için siderefor bağlayıcı protein olarak görev yapmaktadır ${ }^{13}$. Tüm bu özellikleri nedeniyle bakteriyel enfeksiyonların tanı ve izleminde belirteç olarak kullanılabilirliği araştırılmaktadır.

Böbrek hastalıkları ve üriner sistem enfeksiyonlarında, üriner sistem hasarının tespitinde erken belirteç olarak, ayrıca sirozda prognostik belirteç olarak kullanılabileceği farklı çalışmalarda bildirilmiştir ${ }^{9,14,15}$. İdrar yolu enfeksiyonu, toplum kökenli pnömoni ve sepsis hastalarının kanında, ayrıca bakteriyel menenjitli hastaların beyin omurilik sıvısında ve peritonitli hastaların periton sıvısında yüksek NGAL düzeyleri tespit edilmiştir 9,14,16-19.

Bu çalışmada, akut Brusellozis ve Brusellar spondilodiskitli hastalarda NGAL serum düzeylerinin belirlenmesi, hastalığın seyri ve komplikasyonları ile serum NGAL düzeyleri arasında fark olup olmadığının değerlendirilmesi amaçlanmıştır.

\section{GEREÇ ve YÖNTEM}

Bu çalışma, Selçuk Üniversitesi Tıp Fakültesi Etik Kurulu onayı ile gerçekleştirildi (Tarih: 07.06.2017 ve Karar No: 2017/192).

\section{Hasta Popülasyonu}

Bu çalışma, Selçuk Üniversitesi Tıp Fakültesi Enfeksiyon Hastalıkları ve Klinik Mikrobiyoloji Polikliniğine başvuran, akut Brusellozis tanısı alan 240 hasta ve 120 sağlıklı kontrol grubu üzerinde yapıldı. 
Çalışmaya 18 yaş üzerinde gebeliği olmayan ve akut Brusellozis dışında başka akut veya kronik enfeksiyon hastalığı bulunmayan hastalar dahil edildi. Ancak 18 yaş altında olan, gebeliği bulunan ve akut Brusellozis dışında akut veya kronik herhangi bir enfeksiyon hastalığı bulunan hastalar çalışmaya dahil edilmedi. Kontrol grubuna herhangi bir şikayeti olmayan, akut veya kronik bir enfeksiyon hastalığı bulunmayan Brucella STA testi negatif, CRP ve ESR değerleri normal olan gönüllüler alındı. Çalışmaya katılan tüm hastalar ve sağlıklı gönüllülerden aydınlatılmış onam formu alındı.

Akut Brusellozis tanısı; son sekiz hafta içinde ateş, halsizlik, eklem ağrısı, gece terlemesi gibi klinik semptomlar nedeniyle STA testi istenen kişilerde STA testinin 1/160 ve/veya üzerinde olması ya da Brucella STA testinde iki hafta arayla dört kat titre artışı saptanması ve/veya kan kültüründe Brucella spp. üremesiyle konuldu. Bu hastaların demografik verileri, şikayetleri, fizik muayene bulguları ve laboratuvar parametreleri [hemogram, CRP, ESR, ALT, aspartat aminotransferaz (AST), STA, kan kültürü] kaydedildi.

Akut Brusellozis tanısı alan ve bel ağrısı şikayeti olan hastalarda kontrastlı lomber MR görüntüleme yapıldı. Radyolojik olarak spondilodiskit varlığı açısından kontrastlı lomber MR görüntüleri Pourbagher ve arkadaşları tarafından tanımlanan format kullanılarak değerlendirildi ${ }^{20}$.

\section{Nötrofil Jelatinaz İlişkili Lipokalin ve Diğer Belirteçlerin Ölçümü}

Akut Brusellozis tanısı konulan hastalardan tedavi öncesi $5 \mathrm{ml}$ kan örneği alınarak 3000 devirde beş dakika santrifüj edildi ve serumları ayrıldı. Ayrılan serumlar $-80^{\circ} \mathrm{C}$ 'de saklandı. Serumlar, çalışma öncesi 24 saat $+2 /+8^{\circ} \mathrm{C}^{\prime}$ de çözdürüldü. Serumlar, oda sıcaklığına getirildikten sonra lipokalin değerleri insan lipokalin 2 ELISA kiti ile (Shangai Biotech Co. Ltd. Çin) üretici firmanın önerilerine göre, Selçuk Üniversitesi Tıp Fakültesi Tıbbi Mikrobiyoloji Laboratuvarında çalışıldı. Çalışmada kullanılan ELISA kitinin ölçüm aralığı 20 ng/L-6000 ng/L ve duyarlılığı 10.12 ng/L olup sonuçlar kantitatif olarak değerlendirildi.

Selçuk Üniversitesi Tıp Fakültesi Tıbbi Mikrobiyoloji Laboratuvarı'nda, CRP düzeyi nefelometrik yöntemle (Immage 800, Immunochemistry Sysytem, Beckman Coulter, CA 92821, ABD) belirlendi. Hemogram, AST, ALT (Beckman Coulter, CA 92821, ABD) ve ESR (Ali Fax, İtalya) düzeyleri Selçuk Üniversitesi Tıp Fakültesi Tıbbi Biyokimya Laboratuvarında belirlendi.

\section{İstatistiksel Analiz}

Hastalara ait verilerin analizleri "Statistical Package for the Social Sciences (SPSS) 18" ile yapıldı. Tanımlayıc istatistik olarak ortanca (min - maks) ve yüzde dağılım kullanıldı. Kategorik veriler ki-kare testi, sayısal veriler Mann-Whitney $U$ testi ile analiz edildi. Çok değişkenli analizde spondilodiskit pozitifliğine etkili faktörleri değerlendirmek amacıyla Forward LR logistik regresyon analizi kullanıldı. Logistik regresyon analizinin model uyum iyiliği Hosmer ve Lemeshow Testi ile değerlendirildi. Çalışmada $\mathrm{p}<0.05$ istatistiksel olarak anlamlı kabul edildi. 


\section{BULGULAR}

Çalışmaya katılan 240 hastanın yaş ortalaması 42 (18-82) ve 120 kontrol grubunun yaş ortalaması 45 (18-72) olarak saptanmıştır. Hastaların \%44.2'si kadın, \%55.8'i erkek, kontrol grubunun \%47.1'i kadın, \%52.9'u erkek olarak belirlenmiştir. Yaş ve cinsiyet açısından iki grup arasında fark bulunmamıştır ( $p>0.05)$.

Hastaların 132 (\%55)'si hayvancılıkla uğraştığını ve 56 (\%23.3)'sı köy peyniri tükettiğini belirtirken, 52 (\%21.6)'si bulaş yolu ile ilgili bir bilgi vermemiştir. Başvuru şikayetlerine bakıldığında, halsizlik (\%78.8), artralji (\%77.9), gece terlemesi (\%67.1), ateş (\%62.1), bel ağrısı (\%42.5) en sık görülen semptomlar olarak tespit edilmiştir. Çalışmaya katılan 240 hastanın 57 (\%23.7)'sinde spondilodiskit saptanmıştır. Hastaların başvuru anındaki laboratuvar değerleri Tablo I'de verilmiştir.

Akut Brusellozisli hastalarda NGAL ortanca değerleri 456.67 ng/L (101.41 ng/L$5804.41 \mathrm{ng} / \mathrm{L})$, kontrol grubunda NGAL ortanca değerleri $113.84 \mathrm{ng} / \mathrm{L}$ (58.29 ng/L$542.34 \mathrm{ng} / \mathrm{L}$ ) olarak saptanmıştır. NGAL ortanca değerleri, istatistiksel olarak hastalarda, kontrol grubundan yüksek çıkmıştır $(p=0.001)$ (Şekil 1).

Brusellar spondilodiskit saptanan hastalarda NGAL ortanca değerleri $1885.62 \mathrm{ng} / \mathrm{L}$ (143.21 ng/L-5804.41 ng/L), Brusellar spondilodiskit saptanmayanlarda NGAL ortanca değerleri 356.87 ng/L (101.41 ng/L-1874.07 ng/L) olarak saptanmıştır. Bu fark istatistiksel olarak anlamlı bulunmuştur $(\mathrm{p}=0.001)$ (Şekil 2).

Brusellar spondilodiskit saptananlarla saptanmayanlar arasında semptomlar değerlendirildiğinde ateş, halsizlik, artralji, gece terlemesinde fark tespit edilmezken, bel ağrısının Brusellar spondilodiskitlerde yüksek olduğu görülmüştür $(p=0.001)$.

Brusellar spondilodiskit saptanan hastalarda ESR ve CRP değerleri; Brusellar spondilodiskit saptanmayanlardan daha yüksek tespit edilmiş, diğer laboratuvar parametreleri arasında fark olmadığı görülmüştür (Tablo II).

Akut Brusellozis tanısı alan 240 hastanın 186 (\%77.5)'sından kan kültürü alındı. Kan kültürü alınan hastaların 67 (\%36.02)'sinin kültüründe Brucella spp. üremesi tespit edilmiştir. Brusellar spondilodiskit tanısı alan hastalarda kan kültürü pozitifliği oranı, Brusellar spondilodiskit saptanmayanlara göre daha yüksek çıkmıştır. Ayrıca kan kültüründe pozitiflik saptanan hastalarda NGAL düzeyi daha yüksek saptanmıştır $(p=0.001)$.

Tablo I. Akut Brusellozisli Hastaların Laboratuvar Parametreleri

\begin{tabular}{|c|c|c|c|c|c|c|c|c|}
\hline & WBC & HGB & PLT & CRP & ESR & ALT & AST & STA \\
\hline Medyan & 6400 & 12.5 & 191000 & 29 & 33 & 26 & 26 & 320 \\
\hline $\begin{array}{l}\text { (min- } \\
\text { maks) }\end{array}$ & $(460-15000)$ & $(8.6-18.8)$ & $\begin{array}{l}(53000- \\
212000)\end{array}$ & $(0.1-241)$ & $(2-88)$ & $(2-156)$ & $(11-164)$ & $(160-5120)$ \\
\hline
\end{tabular}

WBC: Lökosit sayısı (4000-10000 hüc/mm³), HGB: Hemoglobin (12-16 mg/dl), PLT: Trombosit sayısı (150 000-450 000 hüc/ $\left.\mathrm{mm}^{3}\right)$, CRP: C-reaktif protein $(0-5 \mathrm{mg} / \mathrm{dl})$, ALT: Alanin aminotransferaz (0-50 IU/L), AST: Aspartat aminotransferaz (0-50 IU/L), STA: Standart tüp aglütinasyon testi (0-1/160). 


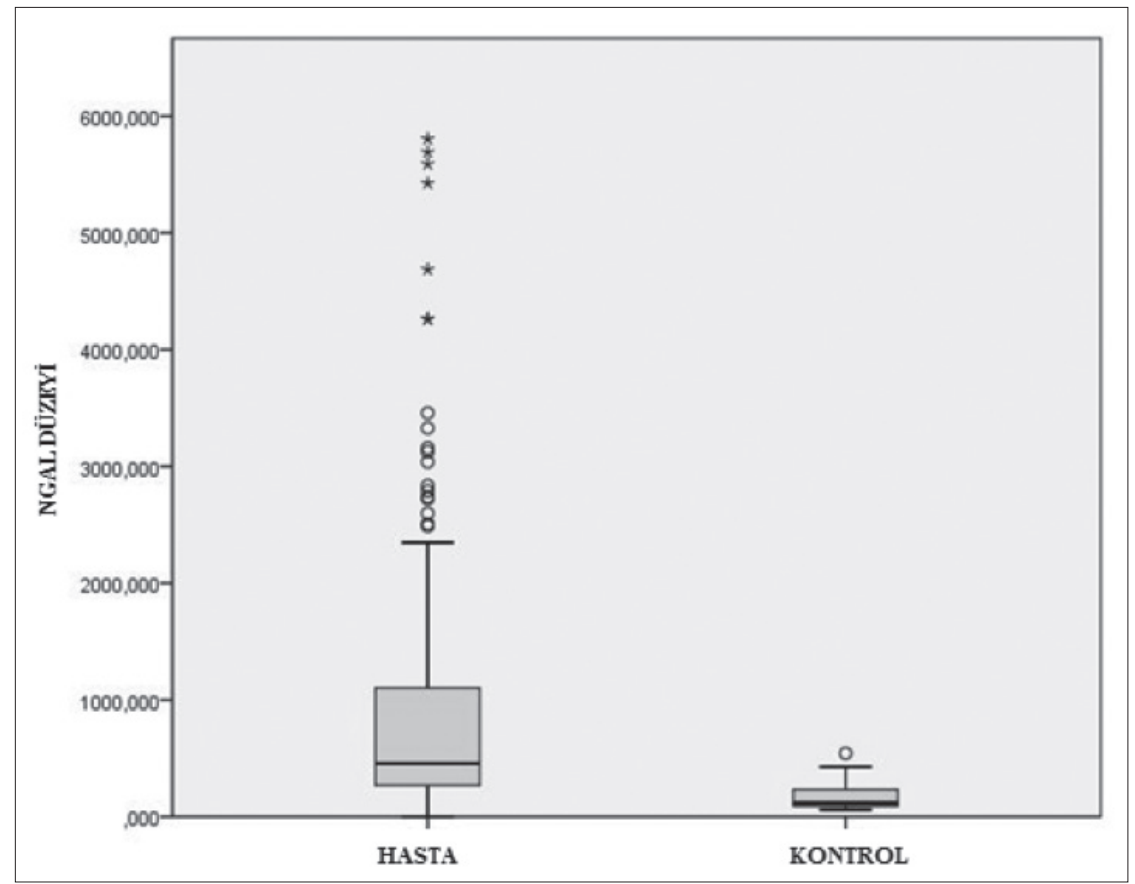

Şekil 1. Hasta ve kontrol grubunda NGAL ortanca değerleri.

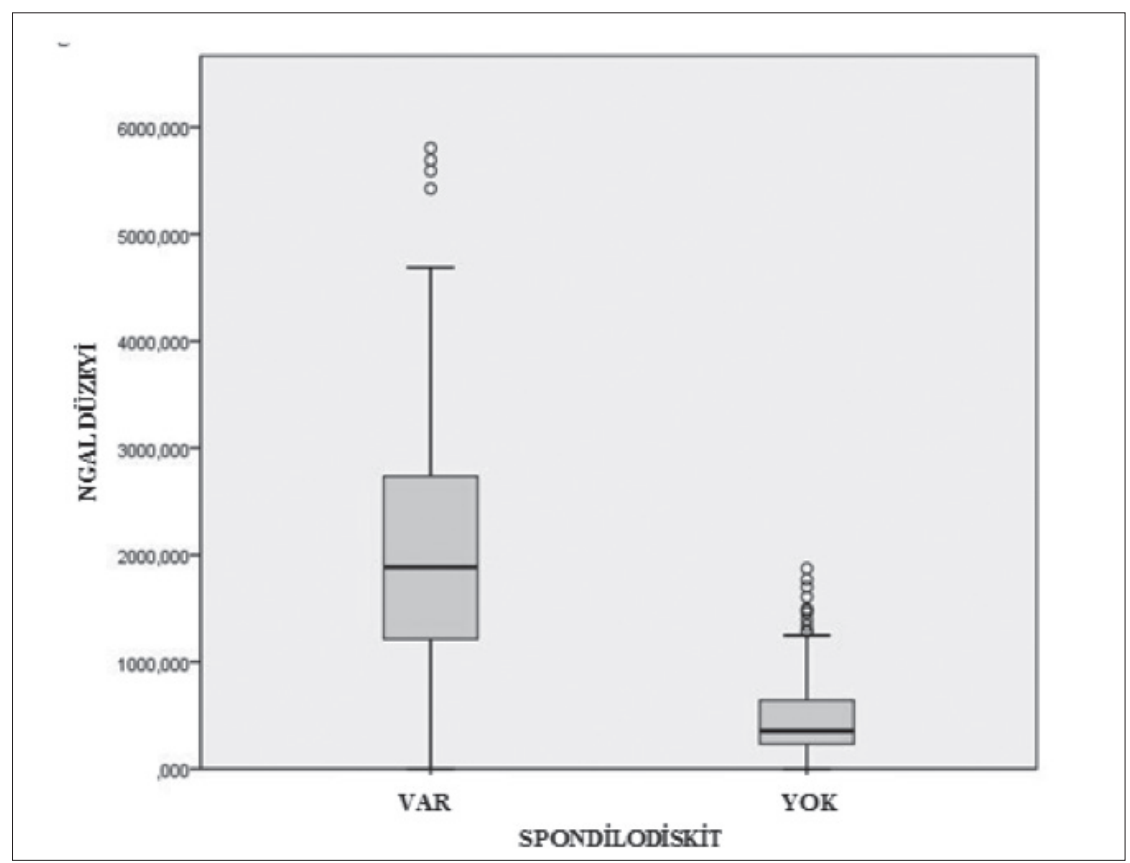

Şekil 2. Akut Brusellozisli hastalardan Brusellar spondilodiskiti olan ve olmayanların NGAL düzeyleri. 


\begin{tabular}{|c|c|c|c|}
\hline Brusellar Spondilodiskit & Var & Yok & $\mathbf{p}$ \\
\hline ESR $(0-20 \mathrm{~mm} / \mathrm{h})$ & $63(26-88)$ & $23(2-87)$ & 0.001 \\
\hline CRP $(0-5 \mathrm{mg} / \mathrm{dl})$ & $55(0.1-241)$ & $20(2-102)$ & 0.001 \\
\hline WBC (4000-10000 hücre/mm³) & $3100(1100-12400)$ & $6700(460-15000)$ & 0.001 \\
\hline
\end{tabular}

\begin{tabular}{|c|c|c|c|}
\hline & Odds ratio & \%95 GA & p \\
\hline Kadın cinsiyet & 4.47 & $1.2-16.1$ & 0.022 \\
\hline ALT & 1.07 & $1.03-1.14$ & 0.001 \\
\hline ESR & 1.06 & $1.02-1.11$ & 0.001 \\
\hline NGAL & 1.002 & $1.001-1.003$ & 0.001 \\
\hline
\end{tabular}

Yapılan regresyon analizinde cinsiyeti kadın olmak, NGAL, ESR ve ALT yüksekliğinin Brusellar spondilodiskiti öngörmede kullanılabileceği tespit edilmiştir. Modelin açıklayıcılığı \%82.3 olarak bulunmuştur (Tablo III).

\section{TARTIŞMA}

NGAL'in birçok bakteriyel enfeksiyonda yararlı bir belirteç olduğunu gösteren çok sayıda çalışma vardır9,14,16-19. Ancak akut Brusellozis ve Brusellar spondilodiskitte NGAL düzeylerinde değişim ve NGAL'in belirteç olarak klinikte kullanılabilirliğini gösteren herhangi bir çalışma yoktur. Çalışmamız, bu konuda yapılmış ilk çalışmadır.

NGAL; bakteriyel enfeksiyonlara karşı savunmada rol alan temel hücreler olan nötrofillerin olgunlaşmasını, adezyonunu, ekstravazasyonunu düzenler. Nötrofiller için kemoatraktan gibi davranır. Nötrofillerin fagositozunu ve bakteriyel öldürmeyi düzenler. Ayrıca demir yüklü bakteriyel sideroforları sekestre ederek mikroorganizmalar tarafından demir alımını önler ${ }^{9,21-25}$. NGAL'in Bruselloziste etkisinin araştırıldığı klinik çalışma olmamakla birlikte, tek deneysel çalışma Hop ve arkadaşlarının Brucella abortus'ta NGAL ilişkili immünolojik mekanizmaları araştırdığı çalışmadır ${ }^{26}$. Bu deneysel çalışmada, NGAL'in iki farklı mekanizma ile B.abortus tarafından demir alımını engellediği ve bunun sonucunda B.abortus bakterisinin çoğalmasını sınırladığı gösterilmiştir. Böylece enfeksiyonun yayılmasının engellenebileceği bildirilmiştir.

Akut Brusellozis ve Brusellar spondilodiskitte NGAL düzeylerinin araştırıldığı çalışmamızda klinik olarak akut Brusellozlu hastalarda kontrol grubuna göre NGAL düzeylerinin belirgin olarak yüksek olduğu tespit edilmiştir (Şekil 1). Bu durum hem nötrofil fonksiyonları ile ilgili olarak hem de bakteriyel sideroforları sınırlamak için NGAL düzeylerinin artması ile ilişkilendirilmiştir. Diğer taraftan Brusellar spondilodiskiti olan akut Brusellozlu hastalarda, 
spondilodiskiti olmayanlara göre NGAL düzeylerinin anlamlı düzeyde yüksek olduğu saptanmıştır (Şekil 2). Spondilodiskit varlığında daha yüksek NGAL düzeylerinin tespit edilmesi, enfeksiyonun ciddiyeti ve komplikasyon gelişiminin bir sonucu olarak değerlendirilmiştir.

Bruselloziste hastalığın seyri ve komplikasyon gelişimini önceden belirleyebilmek için birçok belirteçle yapılan çalışma mevcuttur. Ancak bu belirteçlerin hiçbiri tek başına yol gösterici değildir. Bu amaçla en sık araştırılan akut faz reaktanları ESR ve CRP'dir ${ }^{4-7}$. NGAL'in de proenflamatuvar sitokinlerin salınmasından sonra üretiminin indüklendiği bildirilmiştir ${ }^{9}$. Çalışmamızda Brusellar spondilodiskit varlığında spondilodiskiti olmayan hastalara göre NGAL düzeyleri ile birlikte ESR ve CRP değerleri de yüksek saptanmıştır. Bu durum, proenflamatuvar sitokinlerin NGAL'in salınımını indüklemesi sonucu akut faz reaktanları ile uyumlu artışını göstermiştir.

Akut Brusellozis tanısında altın standart yöntem kan kültürünün pozitifliğidir. Brucella bakterisinin hücre içi bir bakteri olması nedeniyle kültür pozitiflik oranları düşüktür ${ }^{1,2}$. Kan kültür pozitifliği oranı Kayaaslan ve arkadaşlarının çalışmasında $\%$ \%0.2 olarak bildirilirken, Shi ve arkadaşlarının çalışmasında 5 \%5 olarak tespit edilmiştir. Hastalarımızın bir kısmı hastanede yatan, bir kısmı ise ayaktan tedavi alan hastalar olduğu için hastalarımızın sadece \%77.5'inden kan kültürü alınmış ve kan kültürü pozitiflik oranı \%36.02 olarak belirlenmiştir. Brusellar spondilodiskit tanısı alan hastalarda kan kültürü pozitifliği oranı, Brusellar spondilodiskit saptanmayanlara göre daha yüksek bulunmuştur. Ayrıca kan kültüründe pozitiflik saptanan hastalarda NGAL düzeyleri, kan kültürü negatif olan hastalara göre daha yüksek saptanmıştır. Bu durum bakteriyemisi olan kişilerde doğal immün yanıtın daha güçlü olması ve beraberinde bakteriyemi varlığında komplikasyon gelişme riskinin yüksek olması şeklinde yorumlanmıştır.

Akut Bruselloziste en sık görülen komplikasyon olan kas iskelet sistemi tutulumunu öngörmek mümkün değildir. Çalışmamızda akut Brusellozisli hastalarda spondilodiskit gelişme riskini öngörmede kullanılabilecek parametreler regresyon analizinde değerlendirildiğinde kadın cinsiyetinin varlığı, ALT, ESR ve NGAL düzeylerinin yüksekliğinin anlamlı olduğu tespit edilmiştir. Modelin açıklayıcılığı \%82.3 olarak saptanmıştır.

Çalışmamızın en önemli kısıtııı̆̆ı, akut Brusellozis tanısı alan Brusellar spondilodiskiti olan ve olmayan hastaların tedavi yanıtı ile NGAL düzeyleri arasındaki korelasyonun izlenememiş olmasıdır. Bunun yanı sıra tüm hastalardan kan kültürü alınamamış olması ise çalışmamızın bir diğer kısıtlıığı olmuştur.

Sonuç olarak, çalışmamızda klinik olarak akut Brusellozlu hastalarda kontrol grubuna göre, Brusellar spondilodiskitli hastalarda da spondilodiskiti olmayanlara göre NGAL düzeylerinin anlamlı düzeyde yüksek olduğu tespit edilmiştir. Ayrıca akut Brusellozisli hastalarda spondilodiskit gelişme riskini öngörmede kullanılabilecek parametreler regresyon analizinde değerlendirildiğinde, kadın cinsiyetinin varlığı, ALT, ESR ve NGAL düzeylerinin yüksekliğinin anlamlı olduğu saptanmıştır.

NGAL'in enfeksiyon hastalıklarının tanısında kullanılabilirliği araştırılmakla birlikte bu belirtecin özgül bir belirteç olmadığı unutulmamalıdır. Çalışmamızın sonuçları göz önüne 
alındığında akut Brusellozis tanısında ve Brusellar spondilodiskit varlığını ön görmede NGAL yararlı bir belirteç olarak görülmekle birlikte Brusellozisin endemik olduğu bölgelerde klinik pratikte kullanılabilmesi için daha kapsamlı çalışmalar gerekmektedir.

\section{ETIK KURUL ONAYI}

Bu çalışma, Selçuk Üniversitesi Tıp Fakültesi Etik Kurulu onayı ile gerçekleştirildi (Tarih: 07.06.2017 ve Karar No: 2017/192).

\section{ÇIKAR ÇATIŞMASI}

Yazarlar bu makale ile ilgili herhangi bir çıkar çatışması bildirmemişlerdir.

\section{KAYNAKLAR}

1. Gul HC, Erdem H. Brucellosis (Brucella Species), pp: 2584-9. In: Bennett JE, Dolin R, Blaser MJ (eds). Mandell, Douglas, and Bennett's Principles and Practice of Infectious Diseases. 2015, 8th ed. Elsevier Saunders, Philadelphia.

2. Turgut M, Turgut AT, Koşar U. Spinal brucellosis: Turkish experience based on 452 cases published during the last century. Acta Neurochir (Wien) 2006; 148(10): 1033-44.

3. Hop HT, Simborio HL, Reyes AW, Arayan LT, Min W, Lee HJ, et al. Immunogenicity and protective effect of recombinant Brucella abortus Ndk (rNdk) against a virulent strain B. abortus 544 infection in BALB/c mice. FEMS Microbiol Lett 2015; 362(4): 1-6.

4. Aktug Demir N, Kolgelier S, Sumer S, Inkaya AC, Ozcimen S, Demir LS, et al. Serum annexin A2 levels in acute Brucellosis and Brucellar spondylodiscitis. Eur J Clin Microbiol Infect Dis 2014; 33(10): 1855-9.

5. Shi Y, Gao H, Pappas G, Chen Q, Li M, Xu J, et al. Clinical features of 2041 human Brucellosis cases in China. PLoS One 2018; 13(11): e0205500.

6. Kayaaslan B, Bastug A, Aydin E, Akinci E, But A, Aslaner H, et al. A long-term survey of Brucellosis: Is there any marker to predict the complicated cases? Infect Dis (Lond) 2016; 48(3): 215-21.

7. Aktuğ Demir N, Türk Dağı H, Fındık D, Sümer Ş, Ural O, Kölgelier S. The Importance of soluble urokinase plasminogen activator receptor in patients with acute Brucellosis. Nobel Med 2015; 11(1): 87-91.

8. Pappas G, Akritidis N, Basilkovski M, Tisianos E. Brucellosis. N Engl J Med 2005; 352(22): 2325-36.

9. Nasioudis D, Witkin SS. Neutrophil gelatinase-associated lipocalin and innate immune responses to bacterial infections. Med Microbiol Immunol 2015; 204(4): 471-9.

10. Cowland JB, Borregaard N. Molecular characterization and pattern of tissue expression of the gene for neutrophil gelatinase-associated lipocalin from humans. Genomics 1997; 45(1): 17-23.

11. Mishra J, Ma Q, Prada A, Mitsnefes M, Zahedi K, Yang J, et al. Identification of neutrophil gelatinaseassociated lipocalin as a novel early urinary biomarker for ischemic renal injury. J Am Soc Nephrol 2003; 14(10): 2534-43.

12. Xu MJ, Feng D, Wu H, Wang $H$, Chan $Y$, Kolls J, et al. Liver is the major source of elevated serum lipocalin-2 levels after bacterial infection or partial hepatectomy: a critical role for IL-6/STAT3. Hepatology 2015; 61(2): 692-702.

13. Liu M, Prisco M, Drakas R, Searles D, Baserga R. 24p3 in differentiation of myeloid cells. J Cell Physiol 2005; 205(2): 302-9.

14. Rafiei A, Mohammadjafari H, Baz, S, Mirabi AM. Urinary neutrophil gelatinase-associated lipocalin (NGAL) might be an independent marker for anticipating scar formation in children with acute pyelonephritis. J Renal Inj Prev 2015, 4(2): 39-44.

15. Martino FK, Filippi I, Giavarina D, Kaushik M, Rodighiero MP, Crepaldi C, et al. Neutrophil gelatinaseassociated lipocalin in the early diagnosis of peritonitis: the case of neutrophil gelatinase-associated lipocalin. Contrib Nephrol 2012; 178: 258-63. 
16. Hong DY, Kim JW, Paik JH, Jung HM, Baek KJ, Park SO, et al. Value of plasma neutrophil gelatinase-associated lipocalin in predicting the mortality of patients with sepsis at the emergency department. Clin Chim Acta 2016; 452: 177-81.

17. Cullaro G, Kim G, Pereira MR, Brown RS, Verna EC. Ascites neutrophil gelatinase-associated lipocalinildentifies spontaneous bacterial peritonitis and predicts mortality in hospitalized patients with cirrhosis. Dig Dis Sci 2017; 62(12): 3487-94.

18. Chang W, Zhu S, Pan C, Xie JF, Liu SQ, Qiu HB, et al. Predictive utilities of neutrophil gelatinase-associated lipocalin (NGAL) in severe sepsis. Clin Chim Acta 2018; 481: 200-6.

19. Kim JW, Hong DY, Lee KR, Kim SY, Baek KJ, Park SO. Usefulness of plasma neutrophil gelatinase-associated lipocalin concentration for predicting the severity and mortality of patients with community-acquired pneumonia. Clin Chim Acta 2016; 462: 140-5.

20. Pourbagher A, Pourbagher MA, Savas L, Turunc T, Demiroglu YZ, Erol I, et al. Epidemiologic, clinical, and imaging findings in Brucellosis patients with osteoarticular involvement. AJR Am J Roentgenol 2006; 187(4): 873-80.

21. Goetz DH, Holmes MA, Borregaard N, Bluhm ME, Raymond KN, Strong RK. The neutrophil lipocalin NGAL is a bacteriostatic agent that interferes with siderophore-mediated iron acquisition. Mol Cell 2002; 10(5):1033-43.

22. Miethke M, Skerra A. Neutrophil gelatinase-associated lipocalin expresses antimicrobial activity by interfering with I-norepinephrine-mediated bacterial iron acquisition. Antimicrob Agents Chemother 2010; 54(4): 1580-9.

23. Liu Z, Petersen R, Devireddy L. Impaired neutrophil function in $24 \mathrm{p} 3$ null mice contributes to enhanced susceptibility to bacterial infections. J Immunol 2013; 190(9): 4692-706.

24. Schroll A, Eller K, Feistritzer C, Nairz M, Sonnweber T, Moser PA, et al. Lipocalin-2 ameliorates granulocyte functionality. Eur J Immunol 2012; 42(12): 3346-57.

25. La Manna G, Ghinatti G, Tazzari PL, Alviano F, Ricci F, Capelli I, et al. Neutrophil gelatinase-associated lipocalin increases HLA-G(+)/FoxP3(+) T-regulatory cell population in an in vitro model of PBMC. PLoS One 2014; 9(2): e89497.

26. Hop HT, Arayan LT, Huy TXN, Reyes AWB, Baek EJ, Min W, et al. Lipocalin 2 (Lcn2) interferes with iron uptake by Brucella abortus and dampens immunoregulation during infection of RAW 264.7 macrophages. Cell Microbiol 2018; 20(3): e12813. 